\title{
Women, Medieval Commerce, and the Education Gender Gap ${ }^{\#}$
}

\author{
Graziella Bertocchi* \\ Monica Bozzano**
}

\begin{abstract}
We investigate the historical determinants of the education gender gap in Italy in the late nineteenth century, immediately following the country's Unification. We use a comprehensive newly-assembled database including 69 provinces over twenty-year sub-samples covering the 18611901 period. We find robust evidence that female primary school attainment, relative to that of males, is positively associated with the medieval pattern of commerce, along the routes that connected Italian cities among themselves and with the rest of the world. The effect of medieval commerce is particularly strong at the non-compulsory upperprimary level and persists even after controlling for alternative long-term determinants reflecting the geographic, economic, political, and cultural differentiation of medieval Italy. The long-term influence of medieval commerce quickly dissipates after national compulsory primary schooling is imposed at Unification, suggesting that the channel of transmission was the larger provision of education for girls in commercial centers.
\end{abstract}

JEL CODES: E02, H75, I25, J16, N33, O15.

KEYWORDS: Education gender gap, medieval commerce, Italian Unification, political institutions, family types.

\# We thank Tindara Addabbo, Eric Battistin, Davide Cantoni, Carolina Castagnetti, Andrea Ichino, Marco Percoco, Paola Profeta, and seminar participants at the XI Brucchi Luchino Labour Economics Workshop and the University of Pavia for helpful comments. Generous financial support from Fondazione Cassa Risparmio di Modena and the Italian University Ministry is gratefully acknowledged.

*University of Modena and Reggio Emilia, RECent, CEPR, CHILD and IZA. Address: Viale Berengario 51, 41121 Modena, Italy, e-mail graziella.bertocchi@unimore.it.

**University of Modena and Reggio Emilia. Address: Viale Berengario 51, 41121 Modena, Italy, emailmonica.bozzano@unimore.it. 


\section{Introduction}

The reversal of the education gender gap, to the advantage of women, has been part of a quiet revolution which has gradually transformed women's lives in the vast majority of OECD countries (Goldin, 2006). To understand the drivers of this change is tantamount to understand the reasons for the previous, long-standing inferior condition of women. Gender inequality is a multifaceted phenomenon that, beside education, requires consideration of its economic and political dimensions. ${ }^{1}$ Historically, the gender gap in wages and labor force participation has been even deeper than that in education, ${ }^{2}$ not to mention the fact that less than a century ago in most OECD countries women were not even granted the most elementary political rights, i.e., the right to vote. ${ }^{3}$ However, even if the education gender gap only captures the tip of the iceberg, to understand its empirical determinants and its evolution would still represent a crucial advancement which we try to achieve in this paper. We start by assembling a new dataset that covers a sample of Italian provinces in the 1861-1901 period, i.e., the initial forty years after the country's Unification, a time that still witnessed a sizeable gender gap even at the primary school level.

The main hypothesis we test over these data is that the education gender gap is influenced by the medieval pattern of commerce, along the routes that connected Italian cities among themselves and with the rest of the world, with a lower gap in the provinces that were commercial centers in the late Middle Age. Between the end of the thirteenth century and the fourteenth century, Italy was at the center of an active process of expansion of trade, city growth, and economic and social development. This period was in fact characterized by an intensification of international exchange throughout Europe and with the progress of mercantile science and practices. These developments implied the necessity for merchants to acquire considerable skills in arithmetic, bookkeeping, reading, and writing. The idea that in these commercial centers women enjoyed a privileged condition is put forward by a vast historical literature. In a context where women's education was generally neglected, merchant communities were characterized by the fact that women, being often in charge of business operations during their men's year-lasting travels, needed to become economically active and, therefore, literate.

The effect of commerce on the promotion of women's education may have run through a number of parallel channels: on the one hand, the physical absence of men forced women to take charge; on the other, a transfer of duties from men to women was facilitated by the fact that, contrary to other occupations, commerce did not require physical strength; moreover, the fact that women found themselves entrusted not only of trade, but also of children's education, resulted into an intergenerational transmission of the acquired skills, role models, and beliefs.

\footnotetext{
${ }^{1}$ Hausmann et al. (2007) present the components of the Global Gender Gap Index and Bozzano (2012) adapts them to contemporaneous Italian data.

${ }^{2}$ Goldin (2006) traces an economic history of the transformation of American women's status in employment and education and shows that the gender gap in college education has been narrower than the gender gap in labor force participation.

${ }^{3}$ Bertocchi (2011) studies the process of women's enfranchisement in the 1870-1930 period.
} 
The relevance of each of the above-mentioned channels for the position of women in society has already been recognized, in isolation, in the relevant literature. For instance, the impact on women's labor force participation of men's absence - as the result of war - is studied by Duby and Perrot (1998), Goldin (1991), Acemoglu et al. (2004), Doepke et al. (2012), and Goldin and Olivetti (2013). The influence of women's inferior physical strength on human capital accumulation is modeled by Galor and Weil (1996), while a similar argument is advanced by Alesina et al. (2011) to test Boserup's (1970) hypothesis that plough (rather than shifting) cultivation determined the historical gender division of labor. ${ }^{4}$ The role of mothers' education on children's outcomes is stressed by Schultz (2002) and Doepke and Tertilt (2009), while Fogli and Veldkamp (2011) and Fernandez (2012) explore the implications of the associated cultural change. For the case of medieval commerce, all these channels are present and reinforce themselves.

The historiography of the 1861-1901 period we focus on reports that over this crucial time span for Italian history the gender gap in primary school enrollment declines from 12.5 to about 5 percent, ${ }^{5}$ reflecting a general process of gender equalization and also, to some extent, of convergence across pre-Unitary states. We review and expand the available evidence on this period in order to understand whether medieval commerce still exerts a beneficial influence of female enrollment relative to that of males, even after controlling for a number of other potentially relevant geographic, economic, cultural, and political factors, operating over the long run.

In more detail, we perform our empirical investigation as follows. Our dependent variable is a provincial measure of gender equality given by the ratio of female to male enrollment rates in primary school, which we further disaggregated into a lower and an upper level, only the former being compulsory. Medieval commerce is a dummy variable that takes value one if the main town in the province was a commercial hub in late Middle Age, and zero otherwise. We consider five main sets of alternative historical determinants: the geographic characteristics of the provincial territories; the level of prosperity, as captured by a measure of urban population density in 1300; the establishment of an ancient university; the fourteenth-century political regimes; and the prevailing medieval family type. Even after controlling for all the above correlates, and despite the fact that they do matter, we find that medieval commerce - after several centuries - is still affecting gender equality in education in the 1861-1901 period. In particular, we find that its effect on the gender gap in primary enrollment is stronger and statistically more significant for enrollment at the upper primary level, if compared with enrollment at the lower primary level which was compulsory and therefore less likely to be influenced by individual choices.

Our findings are robust to a number of alternative specifications involving variants of dependent variables, regressors, samples, and estimation techniques. To be noticed is also that medieval commerce exerts no significant influence on the level of schooling itself, which underscores its peculiar influence only through gendered human capital accumulation. Moreover, we find that the effect of medieval commerce is declining over our sample, consistently with previous evidence

\footnotetext{
${ }^{4}$ Since the plough system applied to the entire territory of Italy, we cannot impute to this channel regional differences in women's outcomes.

${ }^{5}$ These figures refer to regional data reported by A'Hearn et al. (2011).
} 
pointing to convergence across Italian provinces after Unification. This declining trend helps us to conjecture that the protracted provision of formal and informal schooling for girls in commercial centers is the likely channel through which the influence of medieval commerce manifests itself. Indeed, the fact that its long-term persistence over nearly six centuries quickly dissipates in the span of only four decades suggests that political Unification and the associated implementation of national educational policies imposing compulsory primary education for boys and girls are the crucial driver of convergence to a lesser gap.

Among the few papers that have focused on the education gender gap the one by Becker and Wößmann (2008) is the closest to our approach since they investigate the determinants of girls' education by looking at sub-regional nineteenth-century data within Prussia. While their focal variable is the spread of Protestantism, with its stress on the study of the Bible both for boys and girls, a connection with our findings comes from the coincidence, noticed for instance by Spufford (1995), between the high literacy rates in Protestant regions and their commercial success. The literature on girls' education also include Goldin (1998) and Goldin et al. (2006), who study the historical evolution of secondary and tertiary education, respectively, for American women. Fernandez and Wong (2011) model the determinants of the recent disappearance of the education gender gap in the US, by linking it to economic and social developments. Bertocchi et al. (2012) document a similar trend for Italy, with a reversal of the education gender gap in the post-World War II period.

The rest of the paper is organized as follows. In Section 2 we document the peculiar role of women within merchant communities in medieval Italy. In Section 3 we present our newly-collected dataset on gendered educational attainment at the primary school level in 1861-1901. Section 4 contains the empirical analysis. In Section 5 we discuss the channels through which medieval commerce exerts its influence by describing the evolution of educational policies before and after Italy's Unification. We conclude with Section 6.

\section{Women and trade in medieval Italy}

Between the end of the thirteenth century and the fourteenth century, Italy was at the center of an active process of expansion of trade, city growth, and economic and social development. This period, which is referred to as the "heroic era of the merchant" (Sapori, 1972), was in fact characterized by an intensification of international exchange throughout Europe which was in turn associated with the progress of mercantile science and practices, such as banking, payment tools, marine insurance, as well as mercantile laws and bookkeeping techniques (Gibbins, 1891). These developments implied the necessity, for merchants, not only to reach a basic level of literacy but also to acquire considerable skills in arithmetic, bookkeeping, reading, and writing. One of the consequences was the establishment of abacus schools, i.e., schools with a commerce-directed curriculum that placed special emphasis on mathematics, as well as other disciplines useful for trade. These schools were created by wealthy merchants, with the support of communal authorities, in order to train their sons to take over the family business (Grendler, 1989). However, girls were also admitted to abacus schools, since in merchant families women were frequently in charge of 
business operations. In fact, within merchant communities, women quickly acquired a special role, since during the men's year-lasting travels, their wives, mothers, sisters, and daughters often needed to become literate in order to run the family business (Ricci, 2011). This peculiar position of women in merchant communities is amply documented. The Florentine banker Giovanni Villani reports that in Florence in the early thirteenth century there were between 8,000 and 10,000 "boys and girls" learning to read (Sapori, 1972). In the middle of the fourteenth century Boccaccio's Decameron narrates of a merchant from Genoa who praises his wife, Zinevra Lomellini, for her ability to write, read, and count "as well as a merchant".

Additional evidence on the role of women within trading communities during the Middle Age comes from a literature based on female epistolary writing. These noticeable examples of literate and highly active women invariably come from cities and towns that were involved in commerce (Palermo, 2010; Miglio, 2008). For instance, we can report the case of Margherita Datini, from Prato and Florence: "In Margherita's merchant world, letter writing was a major concern, and her household duties included frequent reports to her absent husband" (Crabb, 2007). Her correspondence with her husband is indeed an example of adaptation of the mercantile letter, a genre of epistolary writing which represented a crucial tool for business operations. In her writings she reported everyday's concerns but also her involvement with her husband's economic and political activities (Byrne, 1996). Another example is Alessandra Strozzi from Florence, whose letters reveal her direct participation in trade as well as in the social and political life of the city of Florence (Doni Garfagnini, 1999).

Evidence of women being literate and actively participating in economic activities is also reported for other Italian commercial centers, such as Venice, Genoa, Palermo, Bari, and Siena. In Genoa, as well as in Florence, women were even investing in the merchant trading companies (Wiesner, 2000). In early thirteenth-century Venice Guglielma Venier, during her husband's absence, took care of the family estate and personally recorded commercial transactions, a task which clearly required an ability to write and count (Ricci, 2011). In the town of Barletta, located within the commercial hub of Bari in Apulia, the presence of women merchants is reported as early as 1280, when the king asks their advice in order to assess the market value of his stock of commodities, while in 1330 another woman, Ferella de Pietrozeczo, is involved in sophisticated ventures involving the commerce of spices (Diviccaro, 1999). The role of women in commerce is documented as early as between the tenth and the twelfth centuries in Amalfi, near Neaples, which having been a maritime republic witnessed a much earlier development of trade, again associated with the emergence of new economic opportunities for women (Skinner, 2004).

A similar association between trade and women's education is found also outside of Italy. Using sources represented again by letters, diaries, and contracts, Uitz (1990) describes the growth of new urban centers across Europe between the twelfth and the fourteenth centuries and stresses how trade radically changed women's lives, by creating new opportunities that were later reflected in widespread changes in the laws regulating women's economic rights. Richardson (1997) illustrates the peculiar position of women in trade in medieval England, again on the basis of their commercial writings. In a subsequent phase, the commercial necessity of literacy is also emphasized by 
Spufford (1995) and invoked by Hoftijzer (2001) in order to explain the relatively high female literacy rates in Amsterdam during the seventeenth century.

\section{Data and descriptive statistics}

In order to study the long-term determinants of the education gender gap, we compile a database on education outcomes in late nineteenth-century Italy drawing from various sources. The main source is represented by data collected by the Italian Ministry of Agriculture, Industry and Commerce (MAIC). Our data cover 69 Italian provinces (at 1871 boundaries) in three points in time (1861, 1881, and 1901), spanning the initial forty years of the unified Kingdom of Italy. This allows us to organise the data as a panel.

It should be stressed that schooling data at the provincial level are only available until 1901, and that data collection at this level of disaggregation is resumed only after World War II. To our knowledge, this is the first time that these early provincial data are employed in econometric analyses.

For our dependent variables, we collect enrollment rates by gender for total population of lower and upper primary school age, which consists of the population between 6 and 12 (excluded) years of age. On this basis we calculate a measure of the education gender gap as the female to male ratio in enrollment rates in primary school. ${ }^{6}$ We also compute a separate measure of the gap at the lower and upper primary school level, only the former being compulsory. ${ }^{7}$ Beside data by gender, we also include general indicators of schooling defined as the number of pupils enrolled in primary school over the number of children of the corresponding 6-12 school age. Again we disaggregate this measure into a lower and an upper primary school level.

To detect the potential role played by history, and in particular the influence of medieval commerce, we create a province-level indicator dating back to the Middle Age. Medieval commerce is a dummy variable that takes value one if the main town in the province was a commercial hub, a fair site, or the seat of a banking institution in late Middle Age, and zero otherwise. Italy was an important fulcrum of international exchange in the period under consideration due to its strategic position at the cross-roads between North-western Europe and the Levant. However not all territories were equally involved. In fact, out of the 69 provinces in our sample, 36 are classified as commercial centers. Beside former maritime republics such as Genoa, Venice, and Pisa, the list includes, for instance, Verona and Ancona, which were hosting trading fairs, as well as Florence and Milan, as important banking centers. The South was also represented, with important trading centers such as, for example, Neaples, Palermo, Messina, Syracuse, and Bari. While Figure 1

\footnotetext{
${ }^{6}$ This measure is equivalent to the UN definition of the Gender Parity Index, where 0 corresponds to extreme inequality and 1 to full equality.

${ }^{7}$ Because of lack of data at the provincial level, the denominators of the enrollment rates at the upper and lower levels are always the corresponding 6-12 population figures.
} 
provides a visual illustration of the pattern of medieval commercial routes in Europe, we refer to the Appendix for more detail on the definitions and sources we employ.

Figure 1. Medieval commercial routes in Europe

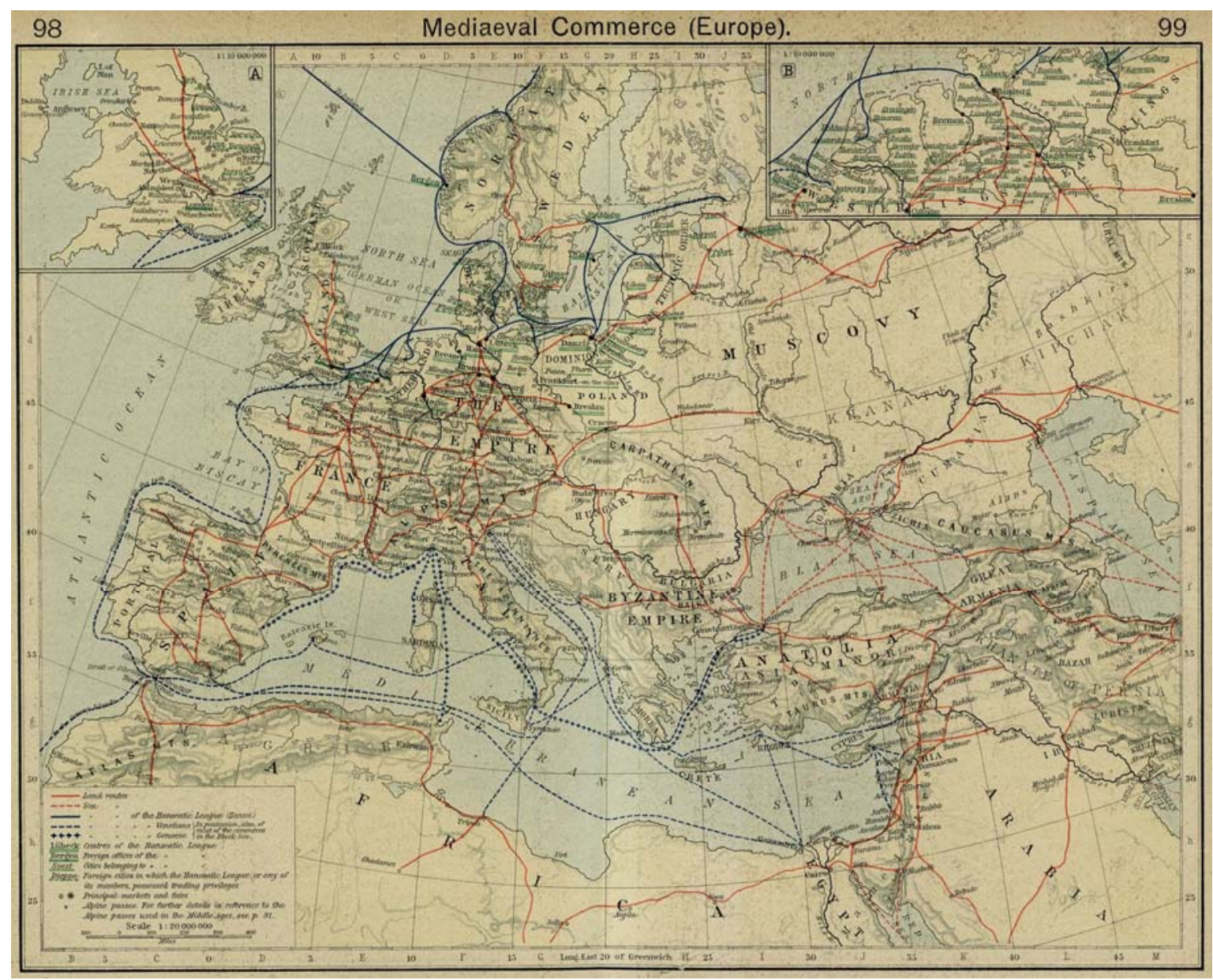

Source: Shepherd (1926).

We also collect data on additional indicators that may suggest alternative long-term determinants of human capital accumulation and its gendered dimension. Beside medieval commerce, we evaluate five potentially confounding factors. First, we consider a set of geographic controls reflecting factor endowment and including latitude, longitude, access to sea, proximity to a river, and mountaineousness of the provincial territory. Second, as a proxy of prosperity, we include urban population density, defined as the ratio of a categorical variable measuring the size of urban population in 1300 , divided by the provincial surface. ${ }^{8}$ Third, to capture the potential influence of the broader cultural environment, we construct a dummy variable for the establishment of a university between the eleventh and the thirteenth, i.e., prior to the expansion of trade. ${ }^{9}$ Fourth, to detect the potential role played by the family in the transmission of gender norms, we include a set of dummy variables reflecting the prevailing family type in the Middle Age in each province

\footnotetext{
${ }^{8}$ To be noticed is that the urban population of a province can be spread over more than one city.

${ }^{9}$ For a review of the history of medieval universities see Rashdall (1987). See also Percoco (2010) and Cantoni and Yuchtman (2012) on the influence of universities on development, in Italy and Germany respectively.
} 
building on the contribution of Todd (1990), who distinguishes for the Italian peninsula three prevailing family types: incomplete stem, communitarian, and egalitarian nuclear. ${ }^{10}$ Following Del Panta et al. (1996), who specifically focus on Italy, we augment Todd's classification to distinguish between two different models of egalitarian nuclear family, which are respectively associated with delayed and early marriage age for women. ${ }^{11}$ As a result, we obtain a set of four dummy variables. $^{12}$ Fifth, to control for the legacy of deeply-rooted political institutions that may have shaped educational policies and the evolution and persistence of gender disparities, we construct a set of dummies for the prevailing political regimes during the fourteenth century: namely, the Signorie, the Communal Republics, the Papal State, the Kingdom of Sicily, and peripheral areas. ${ }^{13}$

While all of the above reflect historical factors, we also collect contemporaneous correlates of economic development, with a panel dimension over the 1861-1901 period. We use measures of the level of wealth and the degree of structural transformation. We proxy the first with the average height of conscripts aged 20. Data on average height for the three waves are taken from A'Hearn et al. (2009). Height is often employed in the economic history literature because it provides researchers with a measure of the stock of nutritional investment and therefore important indirect information on changes in the well-being of populations (Fogel et al., 1982; A'Hearn and Vecchi, 2011). ${ }^{14}$ To measure structural transformation we employ an index of industrialisation computed by Ciccarelli and Fenoaltea (2012) and defined as the share of value added in manufacturing (excluding construction) over the share of the male population over age 15 (data are from census).

To assess whether indicators of education gender gaps converge across provinces after Unification, we also collect measures of initial gendered human capital accumulation. We rely on data on male and female literacy which for most provinces are available for 1861, so that we can construct initial cross-province measures of the gender gap in literacy. ${ }^{15}$ Literacy rates are calculated as the share of individuals aged 5 or older who are able to read and write. The gender gap is measured as the female to male ratio (on a 0-1 range) of literacy rates. ${ }^{16}$ Since literacy data refer to stock information about population in 1861, they effectively embed the outcome of several previous decades of human capital accumulation and educational policies.

\footnotetext{
${ }^{10}$ Todd's classification is organized along two leading axes, residential habits after marriage and inheritance rules: in egalitarian nuclear families children leave after marriage and equal partition applies; children stay on with their parents in incomplete stems and communitarian families, while they are respectively characterized by primogeniture and partition.

${ }^{11}$ The marriage age is a significant indicator of the degree of subordination of women with respect to men and therefore of inequality.

${ }^{12}$ In a European perspective, Todd's classification is employed by Duranton et al. (2009) to study the effect of family structure on various economic outcomes (labor force participation, employment in manufacturing and services, GDP per capita, Gini coefficients) and by Galasso and Profeta (2011) to study pension systems and redistributive policies.

${ }^{13}$ This classification is from De Blasio and Nuzzo (2010).

${ }^{14}$ Since the available data neglect female stature, whose trend does not necessarily mimic that of males, as an alternative proxy of wealth we also consider contemporaneous population density (data are from the census).

${ }^{15}$ For the provinces belonging to today's Veneto and for Mantua initial data refer to 1867, for Rome to 1872: this is due to the fact that the former territories were annexed to the new-born kingdom only in 1866, the latter in 1871.

${ }^{16}$ Data are taken from censuses, where the ability to read and write is reported through the answers to the following question asked to the household head: "How many people in your family are able to read or read and write?".
} 
More details on the definitions and sources of all variables, as well as on methodological issues, can be found in the Appendix.

Our dataset generates a set of stylized facts that can suggest preliminary hypotheses and considerations. The descriptive statistics reported in Table A1 reveal that in primary schools the average enrollment rate is 52.7 percent and the average gender gap is 0.83 (where 1 represents perfect equality). However there exists significant variation across provinces for both outcomes, ranging from 9.7 to 117.3 percent for the enrollment rate and from 0.05 to 1.51 for the gender gap. ${ }^{17}$ Moreover, the picture changes considerably if one focuses on the upper primary level, with an average enrollment rate of only 4 percent and a much larger gender gap at 0.53 . Figure 2 shows the time evolution of enrollment rates for boys and girls across four macro-regions, at the primary level as an aggregate. In the North West - corresponding in 1861 to the Kingdom of Sardinia and Lombardy - schooling rates are uniformly larger for boys and girls, if compared to other areas, while the gender gap is smaller. At the opposite we find the South, ruled by the Bourbons. Despite some evidence of convergence over time, the picture shows that at the end of the period the initial differences are far from eradicated.

Figure 2. Enrollment rates by gender at the primary level, by macro-region, 1861-1901

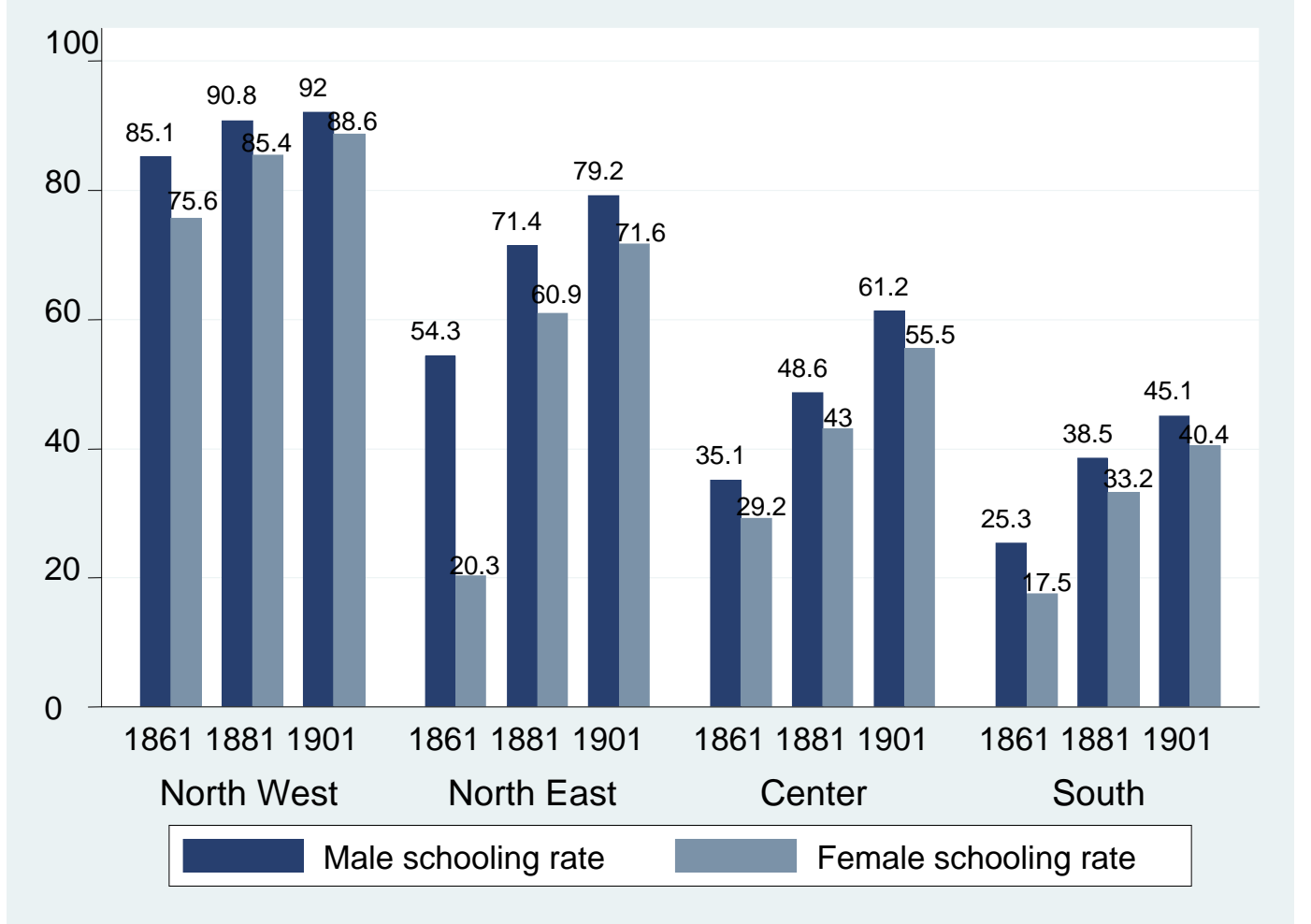

Figure 3 illustrates the same dynamics for the upper level of primary schools, where rates are computed by dividing the number of pupils enrolled by the number of children of the relevant schooling age. Enrollment rates at the upper level are uniformly much lower, presumably because

\footnotetext{
${ }^{17}$ For some observations the ratio is larger than 1, which indicates a gender gap in favor of females.
} 
this level was not mandatory. The gender gap in enrollment is also uniformly larger. North Western provinces lead again, with higher enrollments and lower gap, followed by the Centre and the North East, with the South far behind.

Figure 3. Enrollment rates by gender at the upper primary level, by macro-region, 1861-1901

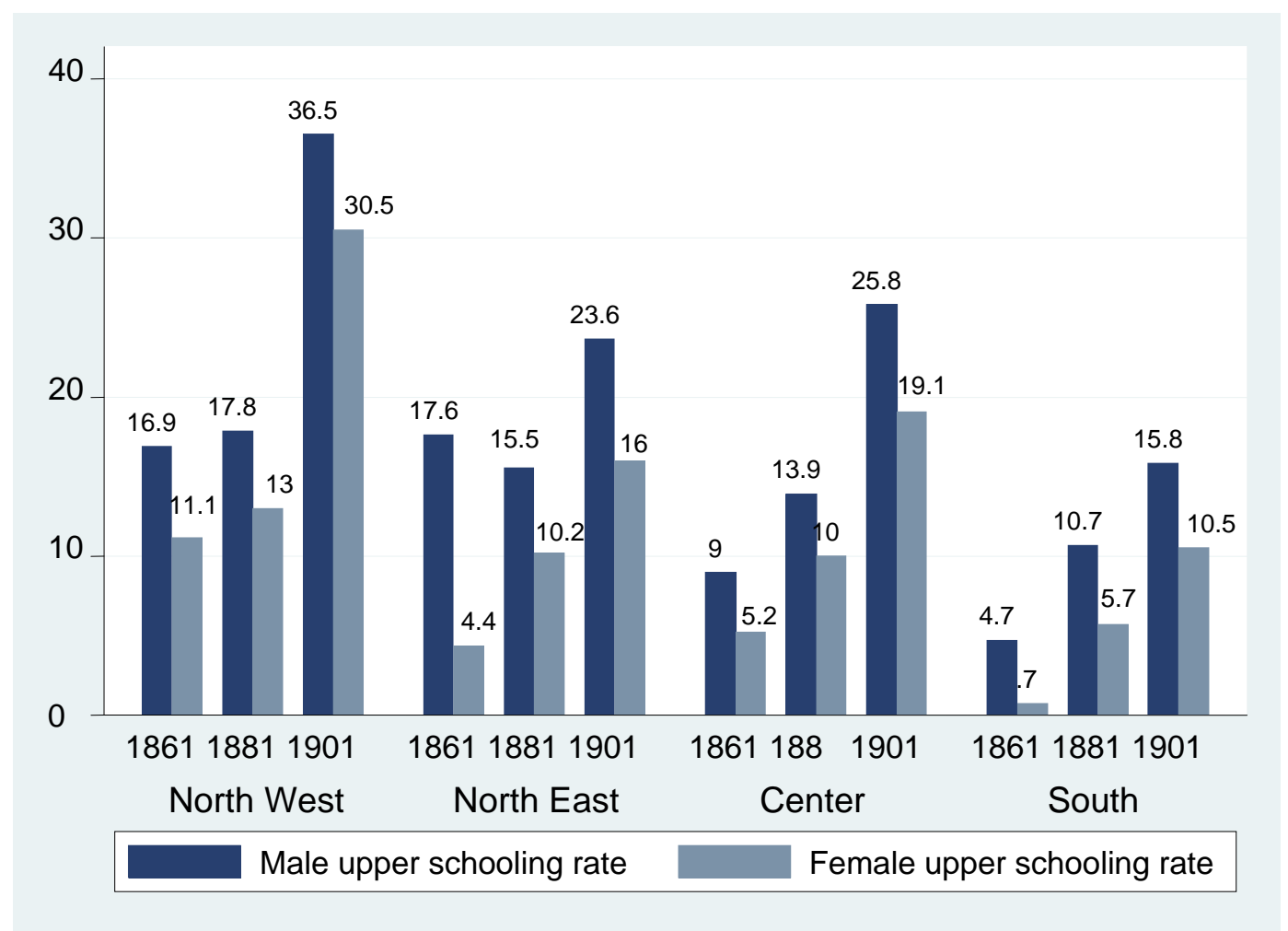

If we look at regional differences in literacy rates at the beginning of the period, we find that the average literacy rate across the provinces is 23 percent, again with a striking divide between North Western territories, at 44 percent, and the rest of Italy, with the South at only 12 percent. The same pattern reappears when we distinguish between males and females: average male literacy is at about 30 percent against 16 percent for women, with pervasive territorial differences.

In an international perspective, it should be noticed that, as of 1861, the gender gap in literacy is not too far from other European countries. ${ }^{18}$ A similar pattern was followed by the gap in primary enrollment: in terms of relative school attainment for boys and girls, in late nineteenth-century Italy - with 77 girls over 100 boys enrolled in primary school - outperforms Spain (60), equals the Netherlands (78), but lags behind most other countries, starting with Great Britain (95), Belgium (94), and Prussia (92). ${ }^{19}$

\footnotetext{
${ }^{18}$ According to Cipolla (1969) the literacy differential between men and women was 14 percentage points, lower than in Spain (21) but twice that of France (7) and Prussia (5).

${ }^{19}$ The source is MAIC (1864).
} 
In Figure 4 we illustrate the bivariate relationship between our focal variable, medieval commerce, and the education gender gap at the primary school level. The figure highlights the fact that provinces that hosted a commercial hub in the Middle Age are associated with a more advantageous condition for women throughout the period under examination and in each region.

Figure 4. The education gender gap at the primary level and medieval commerce, by macro-region, 1861-1901

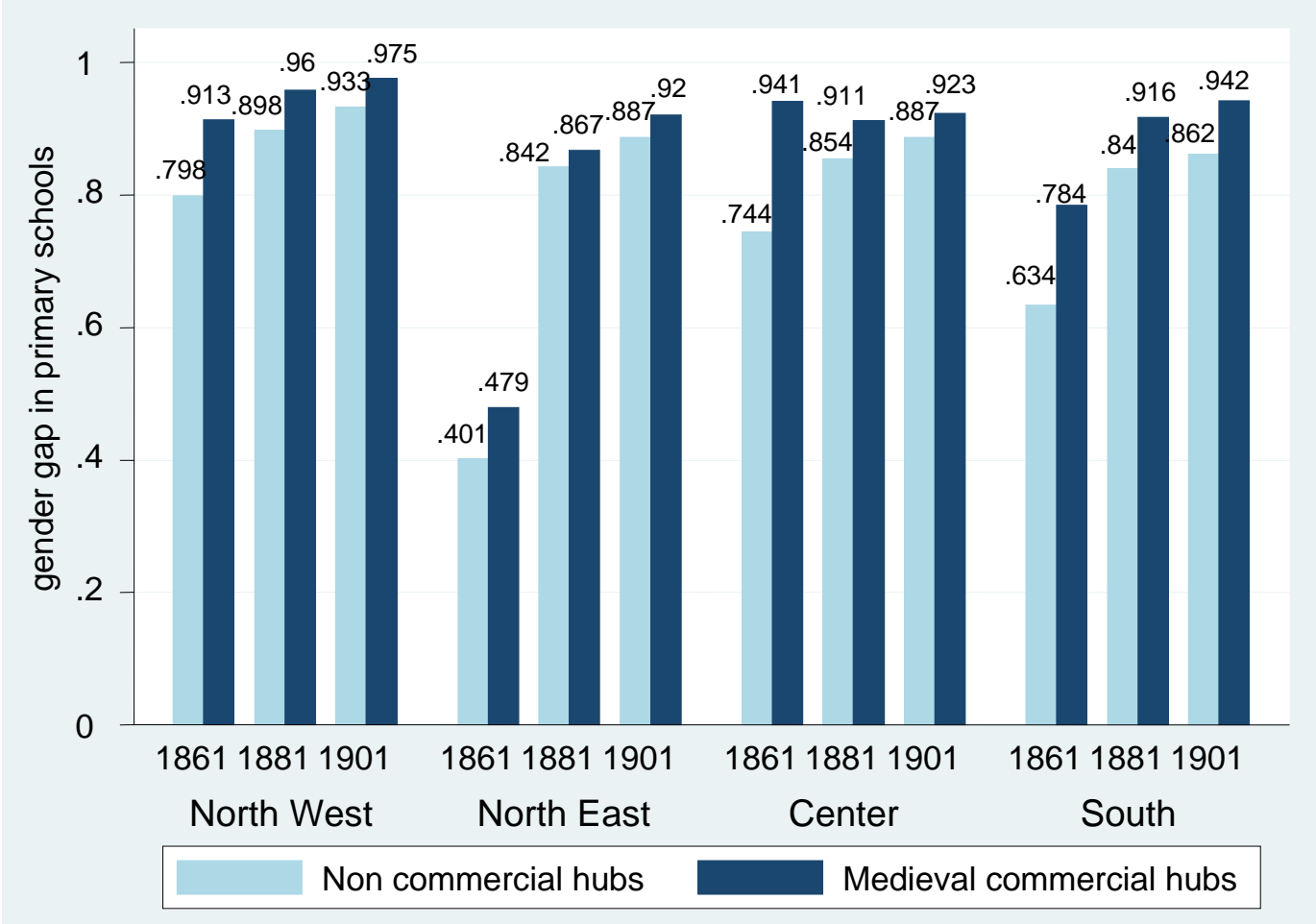

Table 1. The education gender gap and medieval commerce, summary statistics, 1861-1901

\begin{tabular}{|c|c|c|c|c|c|c|c|c|c|}
\hline & \multicolumn{3}{|c|}{$\begin{array}{c}\text { Female to male ratio } \\
\text { schooling rate }\end{array}$} & \multicolumn{3}{|c|}{$\begin{array}{l}\text { Female to male ratio } \\
\text { lower schooling rate }\end{array}$} & \multicolumn{3}{|c|}{$\begin{array}{l}\text { Female to male ratio } \\
\text { upper schooling rate }\end{array}$} \\
\hline & $\begin{array}{l}\text { Whole } \\
\text { sample }\end{array}$ & $\begin{array}{c}\text { Medieval } \\
\text { commercial } \\
\text { hubs }\end{array}$ & Others & $\begin{array}{l}\text { Whole } \\
\text { sample }\end{array}$ & $\begin{array}{c}\text { Medieval } \\
\text { commercial } \\
\text { hubs }\end{array}$ & Others & $\begin{array}{l}\text { Whole } \\
\text { sample }\end{array}$ & $\begin{array}{c}\text { Medieval } \\
\text { commercial } \\
\text { hubs }\end{array}$ & Others \\
\hline Obs & 207 & 108 & 99 & 207 & 108 & 99 & 207 & 108 & 99 \\
\hline Mean & 0.833455 & 0.878014 & 0.784845 & 0.854258 & 0.898148 & 0.806377 & 0.550165 & 0.625681 & 0.467782 \\
\hline Min & 0.058806 & 0.133151 & 0.058806 & 0.045682 & 0.081783 & 0.045682 & 0 & 0 & 0 \\
\hline Max & 1.515913 & 1.515913 & 1.135 & 1.339314 & 1.339314 & 1.162496 & 1.326245 & 1.326245 & 0.898016 \\
\hline T-test & & \multicolumn{2}{|c|}{$\begin{array}{c}0.0932 * * * \\
(0.028)\end{array}$} & \multicolumn{3}{|c|}{$\begin{array}{c}0.0918^{* * *} \\
(0.0295)\end{array}$} & & \multicolumn{2}{|c|}{$\begin{array}{c}0.158^{* * *} \\
(0.036) \\
\end{array}$} \\
\hline
\end{tabular}

T-test is the two-sample mean comparison test $(\mathrm{Ha}=\mathrm{diff} \neq 0)$. Standard errors are reported in parentheses. $*{ }^{* *}$, and $* * *$ denote significance at $10 \%$, $5 \%$, and $1 \%$ levels. 
Equivalently, Table 1 reports descriptive statistics for our measures of gender equality in human capital accumulation distinguishing between provinces that included a commercial center and provinces that did not. Medieval commercial hubs exhibit higher mean scores at all levels of schooling, and their superiority is especially clear at the upper primary level, whit a score of 0.63 against 0.47 for the rest of the sample. These initial observations put forth strong evidence of a relevant effect of the past legacy of trade on subsequent cultural norms regarding gender roles.

\section{Regression results}

\subsection{Pooled OLS}

In order to assess the determinants of education inequalities across gender at the primary school level in Italy, over the 1861-1901 period immediately following the Unification, we start in Table 2 with a set of bivariate OLS regressions on our focal variable, medieval commerce. We present three alternative dependent variables. We first examine the female to male ratio in enrollment rates at the primary level as a whole (Column 1). Enrollment rates are measured as the number of pupils of each gender over the school age (i.e., 6-12 years of age) population of the corresponding gender. Then we turn to the lower and upper primary levels taken separately (Columns 2 and 3, respectively). To be recalled is that our dependent variables should be interpreted as indexes of gender equality in education, so that a positive coefficient indicates that the corresponding regressor is associated with more gender equality and thus a smaller gender gap. The coefficient of medieval commerce is always significantly positive at 1 percent, indicating that provinces that were more closely involved with trade in the period running from the thirteenth to the fourteenth centuries exhibit a more favorable position for women in terms of education. The size of the coefficient is larger at the upper primary level, which is not surprising given that the lower level was compulsory and therefore less likely to display cross-sectional variation. In economic terms, the impact of medieval commerce is sizeable, since a one-standard-deviation increase is associated with an increase of 5.6 percentage points in the sample average of female to male ratio schooling rate. The effect is even stronger, 14.3, at the upper primary level. Qualitatively similar results are obtained in regressions including time dummies and dummies reflecting the four macro-regions, which can be interpreted as spatial fixed effects (Columns 4-6), and also adding controls for geography (i.e., latitude, longitude, access to sea, proximity to a river, and mountaineousness). ${ }^{20}$ The latter set of controls is meant to capture the potential influence of factor endowments which may shape educational attainment in a gendered manner, for instance through agricultural techniques.

\footnotetext{
${ }^{20}$ In a further set of regressions, which we do not report for brevity, we also control for contemporaneous height and industrialization, which are never significant. When male height is replaced by population density similar results are obtained.
} 
Table 2. The determinants of the education gender gap, Italy, 1861-1901: pooled OLS
(1)
(2)
(3)
(4)
(5)

(6)

(7)

(8)

(9)

Dependent variable: Female to male ratio primary schooling rate

\begin{tabular}{ccccccccccc} 
& $\begin{array}{c}\text { Aggregate } \\
\text { level }\end{array}$ & $\begin{array}{c}\text { Lower } \\
\text { level }\end{array}$ & $\begin{array}{c}\text { Upper } \\
\text { level }\end{array}$ & $\begin{array}{c}\text { Aggregate } \\
\text { level }\end{array}$ & $\begin{array}{c}\text { Lower } \\
\text { level }\end{array}$ & $\begin{array}{c}\text { Upper } \\
\text { level }\end{array}$ & $\begin{array}{c}\text { Aggregate } \\
\text { level }\end{array}$ & $\begin{array}{c}\text { Lower } \\
\text { level }\end{array}$ & $\begin{array}{c}\text { Upper } \\
\text { level }\end{array}$ \\
\hline Medieval commerce & $0.0932^{* * *}$ & $0.0918^{* * *}$ & $0.158^{* * *}$ & $0.0817^{* * *}$ & $0.0872^{* * *}$ & $0.106^{* * *}$ & $0.069 * * *$ & $0.081^{* * *}$ & $0.113^{* * *}$ \\
& $(0.0279)$ & $(0.0295)$ & $(0.0360)$ & $(0.0258)$ & $(0.0278)$ & $(0.0237)$ & $(0.0265)$ & $(0.0309)$ & $(0.0240)$
\end{tabular}

Years

Macro-regions

Geography

Obs

R-squared

207

$207 \quad 207$

$\begin{array}{lll}0.05 & 0.05 & 0.09\end{array}$

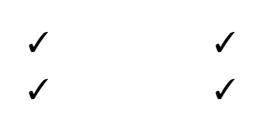

Adj. R-squared

$0.05 \quad 0.04 \quad 0.08$

$\begin{array}{lll}207 & 207 & 207 \\ 0.35 & 0.33 & 0.61 \\ 0.33 & 0.31 & 0.60\end{array}$

2
2
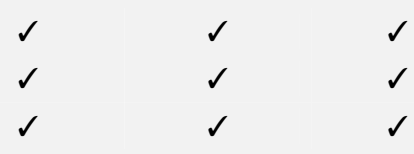

Robust standard errors in parentheses. ${ }^{* * *} \mathrm{p}<0.01,{ }^{* *} \mathrm{p}<0.05,{ }^{*} \mathrm{p}<0.1$. A constant term is always included.

In Table 3 we extend our analysis by regressing the education gender gap on a number of additional, potentially confounding historical covariates. Dummies for time and macro-regions as well as geographical controls are always included. The purpose of this exercise is not meant to deny the important role of additional factors, but simply to demonstrate that the influence of medieval commerce remains strong even accounting for them. Indeed, one could argue that the level of prosperity in medieval times may have a persistent effect of subsequent gender equality, since the latter is often associated with economic progress. Likewise, the presence of an ancient university may also represent a force pushing for a cultural climate more favorable toward women's education. It has also been argued that societies with patriarchal families are associated with an inferior status of women in all realms including education. Finally, different political regimes may have implemented differentiated educational policies along the gender dimension. However, we find that after adding urban population density (Columns 1-3) and the dummies for universities (Columns 4-6), family types (Columns 7-9), and political regimes (Columns 10-12), the estimates for medieval commerce remain robust.

To further check the robustness of our results, we run several other variants of the benchmark regressions in Table 2, Columns 7-9. Rather than OLS with heteroskedasticity-robust standard errors, we run OLS regressions with Newey-West-robust (HAC) standard errors, to correct for heteroskedasticity and autocorrelation. We also modify the dependent variables, using simply the ratio of female to male enrollments, rather than the corresponding rates, and adding the ratio of female over male population of age 6-12, i.e., an (inverted) index of masculinity, as a further control. Next we estimate the same regressions over a sub-sample excluding the provinces located in Veneto and Mantua, which were part of the Austrian territories, as well as Rome. ${ }^{21} \mathrm{We}$ also employ spatial dummies for alternative geographical entities, i.e., the 12 regions defined by the

\footnotetext{
${ }^{21}$ We exclude these provinces because they show missing values for a few variables in the initial wave. See the Appendix for further details.
} 
dummies (for direct comparison with Table 2). Inspection of the coefficients of medieval commerce confirms its significance over each cross section, despite the fact that its influence tends to decline through time. This trend is particularly clear-cut for the upper level, whose coefficient's size declines steadily and also loses significance in 1901, consistently with the evidence reporting substantial convergence in education outcomes across Italian provinces after Unification.

Table 4. The evolution of the education gender gap, Italy, 1861-1901: bivariate cross-sectional OLS
(1)
(2)
(3)
(4)
(5)
(6)
(7)
(8)
(9)

Dependent variable: Female to male ratio primary schooling rate

\begin{tabular}{|c|c|c|c|c|c|c|c|c|c|}
\hline & \multicolumn{3}{|c|}{1861} & \multicolumn{3}{|c|}{1881} & \multicolumn{3}{|c|}{1901} \\
\hline & $\begin{array}{c}\text { Aggregate } \\
\text { level }\end{array}$ & $\begin{array}{c}\text { Lower } \\
\text { level }\end{array}$ & $\begin{array}{l}\text { Upper } \\
\text { level }\end{array}$ & $\begin{array}{c}\text { Aggregate } \\
\text { level }\end{array}$ & $\begin{array}{c}\text { Lower } \\
\text { level }\end{array}$ & $\begin{array}{c}\text { Upper } \\
\text { level }\end{array}$ & $\begin{array}{c}\text { Aggregate } \\
\text { level }\end{array}$ & $\begin{array}{c}\text { Lower } \\
\text { level }\end{array}$ & $\begin{array}{l}\text { Upper } \\
\text { level }\end{array}$ \\
\hline \multirow[t]{2}{*}{ Medieval commerce } & $0.136^{* *}$ & $0.126^{*}$ & $0.167 * * *$ & $0.0566^{* *}$ & $0.0814^{* *}$ & $0.0978 * * *$ & $0.0523 * *$ & $0.0536^{* *}$ & $0.0542 *$ \\
\hline & $(0.0627)$ & $(0.0660)$ & $(0.0518)$ & $(0.0258)$ & $(0.0369)$ & $(0.0328)$ & $(0.0248)$ & $(0.0254)$ & $(0.0322)$ \\
\hline Macro-regions & $\checkmark$ & $\checkmark$ & $\checkmark$ & $\checkmark$ & $\checkmark$ & $\checkmark$ & $\checkmark$ & $\checkmark$ & $\checkmark$ \\
\hline Obs. & 69 & 69 & 69 & 69 & 69 & 69 & 69 & 69 & 69 \\
\hline R-squared & 0.38 & 0.35 & 0.50 & 0.17 & 0.17 & 0.39 & 0.14 & 0.11 & 0.27 \\
\hline Adj. R-squared & 0.34 & 0.31 & 0.47 & 0.11 & 0.12 & 0.35 & 0.08 & 0.06 & 0.23 \\
\hline
\end{tabular}

Robust standard errors in parentheses. ${ }^{* * *} \mathrm{p}<0.01,{ }^{* *} \mathrm{p}<0.05,{ }^{*} \mathrm{p}<0.1$. A constant term is always included.

Table 5. The evolution of the education gender gap, Italy, 1861-1901: pooled OLS

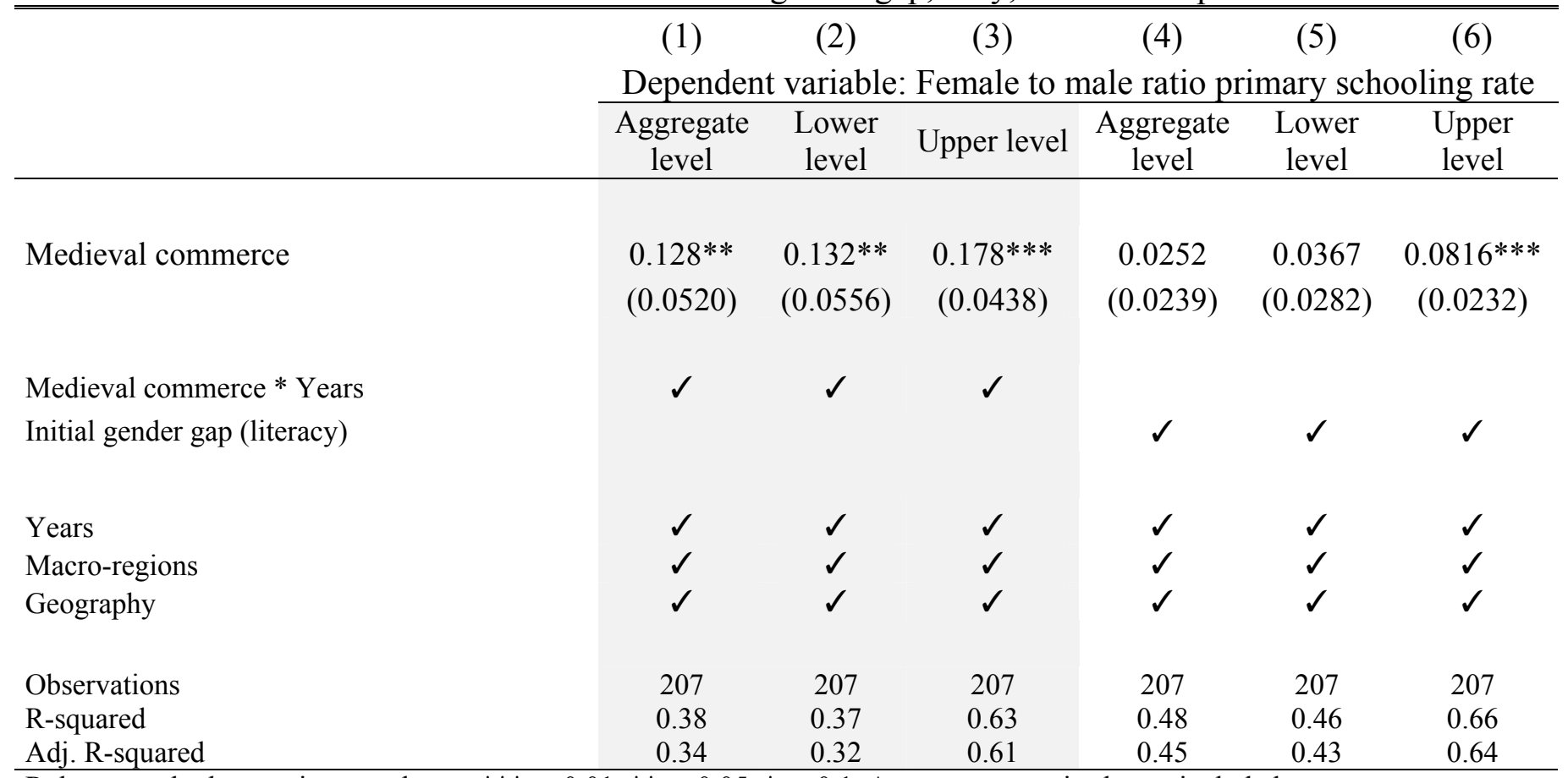

Robust standard errors in parentheses. ${ }^{* * *} \mathrm{p}<0.01,{ }^{* *} \mathrm{p}<0.05,{ }^{*} \mathrm{p}<0.1$. A constant term is always included. 
In Table 5 we return to pooled specifications and in the first set of regressions (Columns 1-3) we add a set of interactions between medieval commerce and the time dummies. The significantly negative coefficient of some of the interactions confirms the results obtained in Table 4, i.e., the influence of medieval commerce is lasting but gradually declining. Next in Columns 4-6 we focus more specifically on the convergence process for the education gap, by adding the 1861 gender gap in literacy, which can be interpreted as a measure of the initial endowment in human capital as well as of gender role norms and beliefs. The fact that its coefficient is highly significant and positive signals the presence of persistence of gender disparities across provinces at the education level. In this specification the coefficient of medieval commerce remains significant only at the upper level, pointing again at a closing of the gap. ${ }^{22}$

\subsection{Schooling}

Despite the fact that our results so far point at a powerful influence of medieval commerce on relative female attainment up to the beginning of the twentieth century, one may wonder whether medieval commerce might have had an influence not only on the gender gap, but more generally on overall schooling. In order to verify whether indeed medieval commerce affected male and female enrollment differently, we now turn to the determinants of schooling. Results are presented in Table 6. In Columns 1-3 we start with three separate measures of the schooling rate: the primary schooling rate is measured as the number of pupils enrolled in primary schools over the population of age 6-12; the lower and upper primary schooling rates are the number of pupils enrolled in lower and upper primary schools, in both cases over the population of age 6-12 (since disaggregated data by age sub-classes are not available at the provincial level). We find that medieval commerce now displays an insignificant coefficient, suggesting that the influence it exerts on female vs. male education up to 1901 has something to do with its peculiar gendered effect. To further explore the gendered effect of medieval commerce on education, we also run separate regressions where the dependent variables are female and male primary enrollment (Columns 4-5) and again commerce is not significant for either dependent variable, even though its coefficient is positive for females and negative for males. The same is true in unreported regressions where the dependent variable is disaggregated between the lower and upper primary level. Controlling for economic development (measured by height and industrialization) yields identical results.

\footnotetext{
${ }^{22}$ Significance is retained also at the lower level when we employ a different source for initial literacy, i.e., data from wedding registers rather than census data.
} 
Table 6. The determinants of schooling, Italy, 1861-1901: pooled OLS

\begin{tabular}{|c|c|c|c|c|c|}
\hline & $(1)$ & $(2)$ & $(3)$ & $(4)$ & $(5)$ \\
\hline & \multicolumn{5}{|c|}{ Dependent variable: Primary schooling rate } \\
\hline & $\begin{array}{c}\text { Aggregate } \\
\text { level }\end{array}$ & $\begin{array}{c}\text { Lower } \\
\text { level }\end{array}$ & $\begin{array}{c}\text { Upper } \\
\text { level }\end{array}$ & Male & Female \\
\hline Medieval commerce & $\begin{array}{c}1.287 \\
(1.527)\end{array}$ & $\begin{array}{c}1.004 \\
(1.586)\end{array}$ & $\begin{array}{c}0.0554 \\
(0.441)\end{array}$ & $\begin{array}{c}-0.317 \\
(1.613)\end{array}$ & $\begin{array}{c}2.881 \\
(1.776)\end{array}$ \\
\hline Years & $\checkmark$ & $\checkmark$ & $\checkmark$ & $\checkmark$ & $\checkmark$ \\
\hline Macro-regions & $\checkmark$ & $\checkmark$ & $\checkmark$ & $\checkmark$ & $\checkmark$ \\
\hline Geography & $\checkmark$ & $\checkmark$ & $\checkmark$ & $\checkmark$ & $\checkmark$ \\
\hline Observations & 207 & 207 & 207 & 207 & 207 \\
\hline R-squared & 0.85 & 0.83 & 0.51 & 0.84 & 0.81 \\
\hline Adj. R-squared & 0.84 & 0.82 & 0.48 & 0.84 & 0.79 \\
\hline
\end{tabular}

\section{Commerce, the gap, and educational policies}

While the evidence so far presented strongly confirms the presence of a relationship between medieval commerce and the education gender gap in post-Unification Italy, in this section we try to identify the channel through which this influence materializes. For the reasons previously explained, our guess is that in merchant communities women received more and better education, both formally and informally. In the absence of detailed data on gendered human capital accumulation during the centuries running between the expansion of trade and Italy's Unification, we will argue that the channel of persistence is to be found in educational policies and their evolution, and in particular in their sudden change after Unification. Our previous estimates show that the effect of medieval commerce, despite being very strong nearly six centuries after its development, is quickly declining over our 40-year sample. This pattern suggests that new and countervailing forces must have been at work after 1861. The single most important event occurring at this critical juncture is indeed the political Unification of the country and the associated adoption and implementation of national educational policies. The primary goal of these policies was indeed the removal of disparities across regions and between genders.

To understand the depth of the innovation introduced with the imposition of compulsory primary education for boys and girls, in this brief narrative we summarize the processes that shaped the evolution of human capital accumulation through the educational system before and after Italy's Unification.

The period immediately preceding Unification, often referred to as Risorgimento, runs from the end of the Napoleonic era in 1815 until 1871 (when Rome becomes the capital). The Unification of Italy represents a key event in the geopolitics of Europe (Dincecco et al., 2011). Before this historical 
turning point Italy was divided among four main dynasties: the Savoys, ruling in the North West, i.e., in Piedmont, Liguria, and Sardinia; the Habsburgs, holding direct control over the LombardyVenetia in the North East, as part of the Austrian Empire, as well as indirect control over the Granduchy of Tuscany and other minor Duchies nearby; the Pope, reigning over Rome and the Center South; and the Bourbons, in charge of the South and the Duchy of Lucca. To be noticed is the partial overlap between these dynasties and the medieval political regimes previously considered.

The pervasive regional differentiation in the institutional and cultural background inherited from Risorgimento represents the initial condition over which the Kingdom of Italy is established. PreUnitary states presented deep differences along several dimensions, including literacy and schooling attainment, partially as a consequence of educational policies (A'Hearn et al., 2011). For instance, if in Lombardy-Venetia schooling was compulsory until age 12 and the Kingdom of Sardinia implemented a long-term plan to regulate the educational system, in the Papal and Bourbons' territories no such policies were present. In some areas of the peninsula there was not even a minimum of what primary school ought to transmit to pupils: rather than being concerned with reading, writing and the first notions of maths, in many cases it reduced to religion and, for girls, knitting, and sewing. ${ }^{23}$ In other cases teachers were illiterate (De Mauro, 1963). Female education was largely neglected (Serristori, 1842) in most areas, with the exception of Lombardy, Rome, and the Duchy of Parma and Piacenza (Vigo, 1971). In the eve of Unification only 27 percent of the adult population, that is only 5 over 22 millions of Italians, were able to read. Only Piedmont and Lombardy showed literacy rates over 40 percent in line with neighbouring countries (A'Hearn et al., 2011).

At the very beginning of the Unification process, the 1859 Casati Law disciplined the school system by introducing an initial compulsory two-year level (extended to three years in 1877 by the Coppino Law) and a subsequent two-year level (Bertocchi and Spagat, 1997; Zamagni, 2002; Bertola and Sestito, 2011). The Casati Law was explicitly inspired by the Prussian system of nationally directed education. The presence of free schools for boys and girls was made mandatory for the local authorities, in the effort to erase the regional differences inherited from the pre-Unitary polities and the differential supply and quality of primary schools. These policies proved effective and contributed to a substantial decline, together with a regional convergence, of the gender gap in education by the end of the nineteenth century. By 1901, as shown by our analysis, the long-term influence of medieval commerce was indeed significantly reduced. The fact that the imposition of compulsory primary education marks the decline of the influence of medieval commerce thus suggests that its channel of persistence did run through the larger provision of education for girls in commercial centers.

\footnotetext{
${ }^{23}$ The so-called "lavori donneschi", i.e., “women's work", continued to be one of the main subjects taught in upper primary schools to girls compared to geometry and technical drawing for boys (Incatasciato, 1978). This gendered distinction in the content of schooling was abrogated only after World War II.
} 


\section{Conclusion}

This work has explored the empirical determinants of the education gender gap in Italy and its evolution in historical perspective. Thus, it represents an advancement within the literature about long-term persistence of deeply-rooted factors of economic and social development. This investigation has been made possible through a newly-assembled dataset that covers a sample of Italian provinces in the 1861-1901 period, i.e., the initial forty years after the country's Unification.

In our search for the determinants of the education gender gap, after controlling for historical factors reflecting the economic, geopolitical, and sociological conditions of medieval Italy, we find robust evidence that the cross-sectional variation of the education gender gap within Italian provinces, throughout the entire 1861-1901 period, is influenced by the medieval pattern of commerce, along the routes that connected Italian cities among themselves and with the rest of the world. The effect of medieval commerce is particularly strong at the non-compulsory, upper primary level. The empirical link we uncover suggests that having a past as a medieval commercial hub might have created the favourable preconditions for the transformation of the mentality concerning the role of women in society, ending up in a more egalitarian set of beliefs transmitted through generations.

A parallel investigation of the determinants of schooling reveals that medieval commerce is no longer a significant determinant, which points to its peculiar influence not so much on overall human capital accumulation but rather on its gendered components. Exploring the convergence process that characterizes the post-Unification period, we find the medieval commerce has a persistent but declining influence over the education gender gap, which suggests that its channel of transmission was the larger provision of education for girls in commercial centers: once compulsory schooling is imposed at the national level at Unification, its long-term influence quickly dissipates in the span of only four decades.

Italy's Unification occurred over a century and a half ago: while the evidence we present refers to the initial forty years, gender equality in education is currently established at the compulsory schooling level, and even reversed for the younger cohorts at the college level. However, in the developing world, discrimination towards girls with respect to educational opportunities is still amply documented, to the point that gender equality in education is one of the eight Millennium Development Goals. This confirms the relevance of our research agenda also for contemporaneous policy actions.

\section{References}

Acemoglu, D., Autor, D.H., Lyle, D., 2004. Women, War, and Wages: The Effect of Female Labor Supply on the Wage Structure at Midcentury. Journal of Political Economy 112, 497-551.

A'Hearn, B., Auria, C., Vecchi, G., 2011. Istruzione. In Vecchi, G. (ed.), In Ricchezza e in Povertà: Il Benessere degli Italiani dall'Unità a Oggi. Il Mulino, Bologna. 159-206.

A'Hearn, B., Peracchi, F., Vecchi, G., 2009. Height and the Normal Distribution: Evidence from Italian Military Data. Demography 46, 1-25. 
Alesina, A.F., Giuliano, P., Nunn, N., 2011. On the Origins of Gender Roles: Women and the Plough. Quarterly Journal of Economics, forthcoming.

Atlante Storico Treccani, 2007. Istituto della Enciclopedia Italiana, Rome.

Becker, S.O., Wößmann, L., 2008. Luther and the Girls: Religious Denomination and the Female Education Gap in Nineteenth-century Prussia. Scandinavian Journal of Economics 110, 777-805.

Benavot, A., Riddle, P., 1988. The Expansion of Primary Education, 1870-1940: Trends and Issues. Sociology of Education 61, 191-210.

Bertocchi, G., 2011. The Enfranchisement of Women and the Welfare State. European Economic Review 55, 535-553.

Bertocchi, G., Brunetti, M., Torricelli, C., 2012. Is It Money or Brains? The Determinants of Intra-Family Decision Power. CEPR Discussion Paper No. 9017.

Bertocchi, G., Spagat, M., 1997. Il Ruolo dei Licei e delle Scuole Tecnico-Professionali tra Progresso Tecnologico, Conflitto Sociale e Sviluppo Economico. In Rossi, N. (ed.), L'Istruzione in Italia: Solo un Pezzo di Carta? Il Mulino, Bologna. 421-459.

Bertola, G., Sestito, P., 2011. A Comparative Perspective on Italy's Human Capital Accumulation. Bank of Italy Economic History Working Papers No. 6.

Boccaccio, G., 1972. The Decameron. McWilliam, G. H. (trans1.). Penguin Books, London.

Boserup, E., 1970. Woman's Role in Economic Development. George Allen and Unwin Ltd., London.

Bozzano, M., 2012. Assessing Gender Inequality among Italian Regions: The Italian Gender Gap Index. University of Pavia, Department of Economics and Quantitative Methods, Quaderni di Dipartimento No. 174.

Buonazia, G., 1870. Documenti sulla Istruzione Elementare del Regno d'Italia, Parte II. Eredi Botta, Florence.

Byrne, J., 1996. Crafting the Merchant's Wife's Tale: Historians and the Domestic Rhetoric in the Correspondence of Margherita Datini (1360-1425). Journals of the Georgia Association of Historians 17, 1-17.

Cantoni, D., Yuchtman, N., 2012. Medieval Universities, Legal Institutions, and the Commercial Revolution. NBER Working Papers No. 17979.

Ciccarelli, C., Fenoaltea, S., 2012. Through the Magnifying Glass: Provincial Aspects of Industrial Growth in Post-Unification Italy. Economic History Review, forthcoming.

Cipolla, C.M., 1969. Literacy and Development in the West. Penguin Books, Harmondsworth.

Crabb, A., 2007. "If I Could Write": Margherita Datini and Letter Writing, 1385-1410. Renaissance Quarterly 60, 1170-1206.

De Blasio, G., Nuzzo, G., 2010. Historical Traditions of Civicness and Local Economic Development. Journal of Regional Science 50, 833-857.

Del Panta, L., Livi Bacci, M., Pinto, G., 1996. La Popolazione Italiana dal Medioevo a Oggi. Laterza, Rome.

De Mauro, T., 1963. Storia Linguistica dell'Italia Unita. Laterza, Bari.

Dincecco, M., Federico, G., Vindigni, A., 2011. Warfare, Taxation, and Political Change: Evidence from the Italian Risorgimento. Journal of Economic History 71, 887-914

Diviccaro, A., 1999. Il Lavoro delle Donne in un Centro di Terra di Bari: Barletta tra XI e XV Secolo. Archivio Storico Pugliese 52, 75-112.

Doepke, M., Hazan, M., Maoz, Y.D., 2012. The Baby Boom and World War II: A Macroeconomic Analysis. Mimeo.

Doepke, M., Tertilt, M. 2009. Women's Liberation: What's In It for Men? Quarterly Journal of Economics 124, 1541-1591. 
Doni Garfagnini, M., 1999. Conduzione Familiare e Vita Cittadina nelle Lettere di Alessandra Macinghi Strozzi. In Zarri, G. (ed.), Per Lettera: La Scrittura Epistolare Femminile tra Archivio e Tipografia. Viella, Rome. 387-411.

Duby, C., Perrot, M., 1998. L’Histoire des Femmes en Occident. Flammarion, Paris.

Duranton, G., Rodriguez-Pose, A., Sandall, R., 2009. Family Types and the Persistence of Regional Disparities in Europe. Economic Geography 85, 23-47.

Fanfani, A., 1968. Storia Economica. Parte Prima. Antichità - Medioevo - Età Moderna. Unione Tipografico-editrice Torinese, Turin.

Fernandez, R., 2012. Cultural Change as Learning: The Evolution of Female Labor Force Participation over a Century. American Economic Review, forthcoming.

Fernandez, R., Wong, J.C., 2011. The Disappearing Gender Gap: The Impact of Divorce, Wages, and Preferences on Education Choices and Women's Work. Mimeo, New York University.

Fogel, R.W., Engerman, S.L., Trussell, J., 1982. Exploring the Uses of Data on Height: The Analysis of Long-Term Trends in Nutrition, Labor Welfare, and Labor Productivity. Social Science History 6, 401-421.

Fogli, A., Veldkamp, L., 2011. Nature or Nurture? Learning and the Geography of Female Labor Force Participation. Econometrica 79, 1103-1138.

Galasso, V., Profeta, P., 2011. When the State Mirrors the Family: The Design of Pension Systems. CEPR Discussion Papers No. 8723.

Galor, O., Weil, D.N., 1996. The Gender Gap, Fertility, and Growth. American Economic Review 86, 274-387.

Gibbins, H. de B., 1891. The History of Commerce in Europe. Macmillan, London.

Goldin, C., 2006. The Quiet Revolution That Transformed Women's Employment, Education, and Family. American Economic Review Papers and Proceedings 96, 1-21.

Goldin, C., 1998. America's Graduation from High School: The Evolution and Spread of Secondary Schooling in the Twentieth Century. Journal of Economic History 58, 345-374.

Goldin, C., 1991. The Role of World War II in the Rise of Women's Employment. American Economic Review 81, 741-756.

Goldin, C., Katz L.F., Kuziemko, I., 2006. The Homecoming of American College Women:

The Reversal of the Gender Gap in College. Journal of Economic Perspectives 20, 133-156.

Goldin, C., Olivetti, C., 2013. Shocking Labor Supply: A Reassessment of the Role of World

War II on U.S. Women's Labor Supply. NBER Working Paper No. 18676.

Grendler, P.F., 1989. Schooling in Renaissance Italy: Literacy and Learning, 1300-1600. Johns Hopkins University Press, Baltimore.

Hausmann, R.D., Tyson, L., Zahidi, S., 2007. The Global Gender Gap Report, World Economic Forum, Geneva.

Hoftijzer, P., 2001. Metropolis of Print: The Amsterdam Book Trade in the Seventeenth Century. In O'Brien, P. (ed.), Urban Achievement in Early Modern Europe: Golden Ages in Antwerp, Amsterdam, and London. Cambridge University Press, New York.

Hicks, J., 1969. A Theory of Economic History. Oxford University Press, London.

Incatasciato, B., 1978. Leggere, Scrivere, Far di Conto. Per una Storia della Didattica nella Scuola Elementare. In Tomasi, T., Genovesi, G., Tancredi Torelli, M.P., Incatasciato, B., Ulivieri, S., Catarsi, E. (eds.), L'Istruzione di Base in Italia (1859-1977). Vallecchi, Florence.

Luzzatto, G., 1963. Storia Economica d'Italia. Il Medioevo. Biblioteca Sansoni, Florence.

MAIC, 1864. Popolazione: Censimento Generale (31 Dicembre 1861). Tipografia Letteraria, Turin.

MAIC, 1865. Statistica del Regno d'Italia. Istruzione Pubblica e Privata. Anno scolastico 186263. Enrico Dalmazzo Tipografo, Turin. 
MAIC, 1868. Statistica del Regno d'Italia, Popolazione, Movimento dello Stato Civile del 1867. Tipografia Tofani, Florence.

MAIC, 1872. Censimento della Popolazione del Regno d'Italia al 31 dicembre 1871. Stamperia Reale, Rome.

MAIC, 1883. Censimento della Popolazione del Regno d'Italia al 31 dicembre 1881. Tipografia Bodoniana, Rome.

MAIC, 1884. Statistica della Istruzione Primaria e Normale per l'Anno Scolastico 1881-82. Tipografia Nazionale, Rome.

MAIC, 1902. Censimento della Popolazione del Regno d'Italia al 10 Febbraio 1901. Tipografia Nazionale Bertero, Rome.

MAIC, 1906. Statistica della Istruzione Primaria e Normale per l'Anno Scolastico 1901-02. Tipografia Nazionale Bertero, Rome.

Malanima, P., 1998. Italian Cities 1300-1861. A Quantitative Approach. Rivista di Storia Economica 14, 91-126.

Miglio, L., 2008. Governare l'Alfabeto. Donne, Scrittura e Libri nel Medioevo. Viella, Rome.

Palermo, M., 2010. Lettere e Epistolografia. In Enciclopedia dell'Italiano, Treccani.it.

Pécout, G., 1999. Il Lungo Risorgimento: La Nascita dell'Italia Contemporanea (1770-1922). Edizioni Bruno Mondadori, Milan.

Percoco, M., 2010. Path Dependence, Institutions, and the Density of Economic Activities: Evidence from Italian Cities. FEEM Nota di Lavoro No. 110.

Rashdall, H., 1987. The Universities of Europe in the Middle Ages. New Edition. Clarendon Press, Oxford.

Ricci, A., 2011. Mercanti e Lingua. In Enciclopedia dell'Italiano, Treccani.it.

Richardson, M., 1997. Women, Commerce, and Rhetoric in Medieval England. In Wertheimer, M. (ed.), Listening to Their Voices: The Rhetorical Activities of Historical Women. University of South Carolina Press, Columbia.

Sacchi, G., 1858. Le Scuole Reali Inferiori ed Elementari nelle Provincie Venete. Annali Universali di Statistica, Economia Pubblica, Legislazione, Storia, Viaggi e Commercio No. 133.

Sapori, A., 1972. La Mercatura Medievale. Sansoni, Florence.

Schultz, T.P., 2002. Why Governments Should Invest More to Educate Girls. World Development 30, 207-225.

Serristori, L., 1842. Statistica dell'Italia. Stamperia Granducale, Florence.

Shepherd, W.R., 1926. Historical Atlas. 5th Edition. Holt, New York.

Skinner, P., 2004. Donne nel Commercio Amalfitano (Secoli X-XII). In Casagrande, G. (ed.), Donne tra Medioevo ed Età Moderna in Italia: Ricerche. Morlacchi, Perugia. 1-22.

Spufford, M., 1995. Literacy, Trade and Religion in the Commercial Centres of Europe. In Davids, K., Licassen, J. (eds.), A Miracle Mirrored: The Dutch Republic in European Perspective. Cambridge University Press, Cambridge. 229-283.

Todd, E., 1990. L'Invention de l'Europe. Seuil, Paris.

Vigo, G., 1971. Istruzione e Sviluppo Economico in Italia nel Secolo XIX, Archivio Economico dell'Unificazione Italiana, Serie II, vol. XVIII. ILTE, Turin.

Uitz, E., 1990. Legend of Good Women: Medieval Women in Towns and Cities. Moyer Bell, New York.

Wiesner, M.E., 2000. Women and Gender in Early Modern Europe. Second Edition. Cambridge University Press, Cambridge.

Zamagni, V., 2002. L'Offerta di Istruzione in Italia 1861-1981: Un Fattore Guida dello Sviluppo o un Ostacolo? In Gilli, G., Lupo, M., Zilli, I. (eds.), Scuola e Società. Le Istituzioni Scolastiche in Italia dall'Età Moderna al Futuro. ESI, Naples. 143-182. 


\section{APPENDIX}

This appendix describes the data underlying our study in more detail. The dataset contains information from 69 Italian provinces at 1871 boundaries. We collect province-level data for three points in time $(1861,1881,1901)$ spanning the first forty years after Italian Unification. Table A1 contains variable definitions and sources. Information on the construction of the dataset follows next. Table A2 presents summary statistics.

Table A1. Variable definitions and sources

\begin{tabular}{|c|c|c|c|}
\hline Variable & Definition & Construction & Main Source \\
\hline Schooling rate & $\begin{array}{l}\text { Gross primary school } \\
\text { enrollment rate }\end{array}$ & $\begin{array}{l}\text { Pupils enrolled in primary } \\
\text { school/population of primary } \\
\text { school age }(6-12) * 100\end{array}$ & MAIC (various years) \\
\hline $\begin{array}{l}\text { Lower schooling } \\
\text { rate }\end{array}$ & $\begin{array}{l}\text { Gross lower primary } \\
\text { school enrollment rate }\end{array}$ & $\begin{array}{l}\text { Pupils enrolled in lower primary } \\
\text { school/ population of primary } \\
\text { school age }(6-12) * 100\end{array}$ & MAIC (various years) \\
\hline $\begin{array}{l}\text { Upper schooling } \\
\text { rate }\end{array}$ & $\begin{array}{l}\text { Gross upper primary } \\
\text { school enrollment rate }\end{array}$ & $\begin{array}{l}\text { Pupils enrolled in upper primary } \\
\text { school/ population of primary } \\
\text { school age }(6-12) * 100\end{array}$ & MAIC (various years) \\
\hline $\begin{array}{l}\text { Male schooling } \\
\text { rate }\end{array}$ & $\begin{array}{l}\text { Male gross primary } \\
\text { school enrollment rate }\end{array}$ & $\begin{array}{l}\text { Male pupils enrolled in primary } \\
\text { school/ male population of } \\
\text { primary school age }(6-12) * 100\end{array}$ & MAIC (various years) \\
\hline $\begin{array}{l}\text { Female } \\
\text { schooling rate }\end{array}$ & $\begin{array}{l}\text { Female gross primary } \\
\text { school enrollment rate }\end{array}$ & $\begin{array}{l}\text { Female pupils enrolled in } \\
\text { primary school/ female } \\
\text { population of primary school } \\
\text { age }(6-12) * 100\end{array}$ & MAIC (various years) \\
\hline $\begin{array}{l}\text { Female to male } \\
\text { ratio schooling } \\
\text { rate }\end{array}$ & $\begin{array}{l}\text { Female gross primary } \\
\text { school enrollment rate } \\
\text { over male gross } \\
\text { primary school } \\
\text { enrollment rate (range } \\
0-1 \text { ) = Gender Parity } \\
\text { Index in primary } \\
\text { school }\end{array}$ & $\begin{array}{l}\text { [Female pupils enrolled in } \\
\text { primary school/ female } \\
\text { population of primary school } \\
\text { age }(6-12)] / \text { [male pupils } \\
\text { enrolled in primary school/ male } \\
\text { population of primary school } \\
\text { age }(6-12)] \text { = female pupils } \\
\text { enrolled in primary school/ male } \\
\text { pupils enrolled in primary school } \\
* \text { masculinity of primary school } \\
\text { age }(6-12) \text { population }\end{array}$ & MAIC (various years) \\
\hline $\begin{array}{l}\text { Female to male } \\
\text { ratio upper } \\
\text { schooling rate }\end{array}$ & $\begin{array}{l}\text { Female gross upper } \\
\text { primary school } \\
\text { enrollment rate over } \\
\text { male gross upper } \\
\text { primary school } \\
\text { enrollment rate (range } \\
0-1 \text { ) = Gender Parity } \\
\text { Index in upper } \\
\text { primary school }\end{array}$ & $\begin{array}{l}\text { Female pupils enrolled in upper } \\
\text { primary school/ male pupils } \\
\text { enrolled in upper primary school } \\
\text { * masculinity of primary school } \\
\text { age (6-12) population }\end{array}$ & MAIC (various years) \\
\hline $\begin{array}{l}\text { Female to male } \\
\text { ratio lower } \\
\text { schooling rate }\end{array}$ & $\begin{array}{l}\text { Female gross lower } \\
\text { primary school } \\
\text { enrollment rate over } \\
\text { male gross lower } \\
\text { primary school } \\
\text { enrollment rate (range } \\
0-1 \text { ) = Gender Parity } \\
\text { Index in lower }\end{array}$ & $\begin{array}{l}\text { Female pupils enrolled in lower } \\
\text { primary school/ male pupils } \\
\text { enrolled in lower primary school } \\
* \text { masculinity of primary school } \\
\text { age (6-12) population }\end{array}$ & MAIC (various years) \\
\hline
\end{tabular}




\begin{tabular}{|c|c|c|c|}
\hline & primary school & & \\
\hline Masculinity & $\begin{array}{l}\text { Masculinity of } \\
\text { primary school age (6- } \\
\text { 12) population }\end{array}$ & $\begin{array}{l}\text { Male population of primary } \\
\text { school age (6-12)/ female } \\
\text { population of primary school } \\
\text { age (6-12) }\end{array}$ & Census (various years) \\
\hline $\begin{array}{l}\text { Medieval } \\
\text { commerce }\end{array}$ & & $\begin{array}{l}\text { Dummy variable: } 1 \text { if main town } \\
\text { lies on medieval commerce } \\
\text { routes or was a commercial hub, } \\
\text { fair or bank seat in late Middle } \\
\text { Age, } 0 \text { otherwise }\end{array}$ & $\begin{array}{l}\text { Fanfani (1968), } \\
\text { Luzzatto (1863), } \\
\text { Atlante Storico } \\
\text { Treccani (2007), } \\
\text { Shepherd (1926) }\end{array}$ \\
\hline Latitude & & $\begin{array}{l}\text { Latitude of the main city of the } \\
\text { province in decimal degrees. }\end{array}$ & Passim \\
\hline Longitude & & $\begin{array}{l}\text { Longitude of the main city of the } \\
\text { province in decimal degrees. }\end{array}$ & Passim \\
\hline Mountainousness & & $\begin{array}{l}\text { Percentage of mountainous } \\
\text { surface over the total surface of } \\
\text { the province }\end{array}$ & Passim \\
\hline Sea & & $\begin{array}{l}\text { Dummy variable: } 1 \text { if the } \\
\text { province is located on a sea, } 0 \\
\text { otherwise }\end{array}$ & $\begin{array}{l}\text { Atlante Storico } \\
\text { Treccani (2007) }\end{array}$ \\
\hline River & & $\begin{array}{l}\text { Dummy variable: } 1 \text { if the } \\
\text { province is located on a } \\
\text { navigable river, } 0 \text { otherwise }\end{array}$ & $\begin{array}{l}\text { Atlante Storico } \\
\text { Treccani (2007) }\end{array}$ \\
\hline $\begin{array}{l}\text { Urban } \\
\text { population } \\
\text { density }\end{array}$ & & $\begin{array}{l}\text { Total population (in thousands) } \\
\text { of all cities belonging to a } \\
\text { province (at } 1871 \text { boundaries) } \\
\text { in } 1300 \text { /provincial surface in } \\
\text { squared kilometers. }\end{array}$ & Malanima (1998) \\
\hline University & & $\begin{array}{l}\text { Dummy variable: } 1 \text { if the main } \\
\text { town of the province is the seat } \\
\text { of ancient university or studium, } \\
0 \text { otherwise }\end{array}$ & Rashdall (1987) \\
\hline $\begin{array}{l}\text { Egalitarian } \\
\text { nuclear family } \\
\text { with early } \\
\text { marriage }\end{array}$ & & $\begin{array}{l}\text { Dummy variable: } 1 \text { if the } \\
\text { egalitarian nuclear family type } \\
\text { with early marriage prevailed in } \\
\text { the Middle Ages, } 0 \text { otherwise }\end{array}$ & $\begin{array}{l}\text { Todd (1990), Del Panta } \\
\text { et al. (1996) }\end{array}$ \\
\hline $\begin{array}{l}\text { Egalitarian } \\
\text { nuclear family } \\
\text { with delayed } \\
\text { marriage }\end{array}$ & & $\begin{array}{l}\text { Dummy variable: } 1 \text { if the } \\
\text { egalitarian nuclear family type } \\
\text { with late marriage prevailed in } \\
\text { the Middle Ages, } 0 \text { otherwise }\end{array}$ & $\begin{array}{l}\text { Todd (1990), Del Panta } \\
\text { et al. (1996) }\end{array}$ \\
\hline $\begin{array}{l}\text { Incomplete stem } \\
\text { family }\end{array}$ & & $\begin{array}{l}\text { Dummy variable: } 1 \text { if the } \\
\text { incomplete stem family type } \\
\text { prevailed in the Middle Ages, } 0 \\
\text { otherwise }\end{array}$ & $\begin{array}{l}\text { Todd (1990), Del Panta } \\
\text { et al. (1996) }\end{array}$ \\
\hline $\begin{array}{l}\text { Communitarian } \\
\text { family }\end{array}$ & & $\begin{array}{l}\text { Dummy variable: } 1 \text { if the } \\
\text { communitarian family type } \\
\text { prevailed in the Middle Ages, } 0 \\
\text { otherwise }\end{array}$ & $\begin{array}{l}\text { Todd (1990), Del Panta } \\
\text { et al. (1996) }\end{array}$ \\
\hline $\begin{array}{l}\text { Communal } \\
\text { Republic }\end{array}$ & & $\begin{array}{l}\text { Dummy variable: } 1 \text { if the } \\
\text { province was a Communal } \\
\text { Republic in the fourteenth } \\
\text { century, } 0 \text { otherwise }\end{array}$ & $\begin{array}{l}\text { De Blasio and Nuzzo } \\
(2010)\end{array}$ \\
\hline Signoria & & $\begin{array}{l}\text { Dummy variable: } 1 \text { if the } \\
\text { province was ruled by a Signoria } \\
\text { in the fourteenth century, } 0 \\
\text { otherwise }\end{array}$ & $\begin{array}{l}\text { De Blasio and Nuzzo } \\
(2010)\end{array}$ \\
\hline
\end{tabular}




\begin{tabular}{|c|c|c|c|}
\hline Papal State & & $\begin{array}{l}\text { Dummy variable: } 1 \text { if the } \\
\text { province was ruled by the Pope } \\
\text { in the fourteenth century, } 0 \\
\text { otherwise }\end{array}$ & $\begin{array}{l}\text { De Blasio and Nuzzo } \\
\text { (2010) }\end{array}$ \\
\hline $\begin{array}{l}\text { Kingdom of } \\
\text { Sicily }\end{array}$ & & $\begin{array}{l}\text { Dummy variable: } 1 \text { if the } \\
\text { province was under the } \\
\text { Kingdom of Sicily in the } \\
\text { fourteenth century, } 0 \text { otherwise }\end{array}$ & $\begin{array}{l}\text { De Blasio and Nuzzo } \\
(2010)\end{array}$ \\
\hline Peripheral areas & & $\begin{array}{l}\text { Dummy variable: } 1 \text { if the } \\
\text { province was a peripheral area in } \\
\text { the fourteenth century, } 0 \\
\text { otherwise }\end{array}$ & $\begin{array}{l}\text { De Blasio and Nuzzo } \\
(2010)\end{array}$ \\
\hline Height & & $\begin{array}{l}\text { Average height at age } 20 \text { of } \\
\text { military conscripts }\end{array}$ & A'Hearn et al. (2011) \\
\hline Industrialization & & $\begin{array}{l}\text { Provincial index of relative } \\
\text { industrialization calculated on } \\
\text { the basis of census data as the } \\
\text { share of industrial value added, } \\
\text { excluding construction, over the } \\
\text { share of the male population } \\
\text { over age } 15\end{array}$ & $\begin{array}{l}\text { Ciccarelli and } \\
\text { Fenoaltea (2012) }\end{array}$ \\
\hline $\begin{array}{l}\text { Female to male } \\
\text { ratio literacy } \\
1861\end{array}$ & $\begin{array}{l}\text { Percentage of literate } \\
\text { females over female } \\
\text { population aged } 5 \text { or } \\
\text { more in } 1861 / \\
\text { percentage of literate } \\
\text { males over male } \\
\text { population aged } 5 \text { or } \\
\text { more in } 1861= \\
\text { Gender Parity Index in } \\
\text { literacy in } 1861 \text { (range } \\
0-1 \text { ) }\end{array}$ & $\begin{array}{l}\text { (Female population able to read } \\
\text { and write in } 1861 / \text { female } \\
\text { population aged } 5 \text { or more in } \\
1861 \text { / (male population able to } \\
\text { read and write in } 1861 / \text { male } \\
\text { population aged } 5 \text { or more in } \\
1861 \text { ) }\end{array}$ & MAIC (1864) \\
\hline Savoys & & $\begin{array}{l}\text { Dummy variable: } 1 \text { if the } \\
\text { province was ruled by the } \\
\text { Savoy-Carignano dynasty prior } \\
\text { to Unification, } 0 \text { otherwise }\end{array}$ & Pécout (1999) \\
\hline Habsburgs & & $\begin{array}{l}\text { Dummy variable: } 1 \text { if the } \\
\text { province was ruled by the } \\
\text { Habsburg dynasty prior to } \\
\text { Unification, } 0 \text { otherwise }\end{array}$ & Pécout (1999) \\
\hline Pope & & $\begin{array}{l}\text { Dummy variable: } 1 \text { if the } \\
\text { province was ruled by the Pope } \\
\text { prior to Unification, } 0 \text { otherwise }\end{array}$ & Pécout (1999) \\
\hline Bourbons & & $\begin{array}{l}\text { Dummy variable: } 1 \text { if the } \\
\text { province was ruled by the } \\
\text { Bourbon dynasty prior to } \\
\text { Unification, } 0 \text { otherwise }\end{array}$ & Pécout (1999) \\
\hline
\end{tabular}

\section{Methodological notes}

Enrollment rates: We collect data for 1861, 1881, and 1901. Due to historical circumstances, we encountered a few problems because of lack of data in particular referring to the first wave. This arises from the fact that the Italian Unification process was a gradual process and therefore official statistical annuals could not take into account those provinces which entered the Italian Kingdom only in subsequent years. As a result data on enrollments are constructed from various sources and 
mainly from Statistica del Regno d'Italia, Istruzione pubblica e privata, a statistical series compiled and published by the Ministry of Agriculture, Industry and Commerce (MAIC) from 1865 to 1906, and from Vigo (1971). For most provinces we impute to 1861 enrollment data referring to 1862-63. For provinces belonging to today's Veneto data on enrollments for the first wave refer to 1856 and are from Buonazia (1870) and Vigo (1971) for primary school and Sacchi (1858) for upper primary school. For Mantua data refer to 1851 and are from Vigo (1971) for primary school and from MAIC (1872) for upper primary school. For Rome (and Comarca) data refer to 1858 and are from Vigo (1971) for primary school and from MAIC (1872) for upper primary school.

To determine enrollment rates, we consider 6-12 (excluded) as the relevant primary school age. In calculating lower and upper primary schooling rates we still employ the population 6-12 (excluded) because we have no data for the specific grade ages. Therefore at the lower and upper level we have an unadjusted measure of enrollment (Benavot and Riddle, 1988) which induces a downward bias in the measure of enrollment rates.

In some cases gross enrollment rates are greater than $100 \%$ and this is due to under-aged and/or over-aged enrollment with respect to the school age being considered (and this is even more compelling during a period of expansion of mass education with a high incidence of late entrance). However, information on net rates (defined as the ratio between the enrollment of age 6-12 over the population of age 6-12) is not available.

Medieval commerce: This variable is a dummy taking value 1 if the main city was on medieval commercial routes or was the seat of a fair or a bank in the thirteenth to fourteenth centuries, 0 otherwise. This indicator is constructed on the basis of two major maps of the period collected by Shepherd (1926) and by the atlas Atlante Storico Treccani (2007) and by crossing this information with information contained in Fanfani (1968) and Luzzatto (1963). Since there is no comprehensive source of information on the status of commercial centers in the Middle Age we are aware of the possible underestimation of the number of medieval commercial hubs. Figure 2 offers a visual illustration of the pattern of commercial routes and fairs as taken from Shepherd (1926).

Urban population density: We aggregate data on the total population (in thousands) living in all cities within a given province (at 1871 boundaries) in 1300 and we divide it by the provincial surface in squared kilometers. The source for population is Malanima (1998), who provides estimates of the populations of Italian cities with more than 5,000 inhabitants on a centennial basis over the period 1300-1861.

University: We create a dummy variable that equals 1 for the presence of an ancient university or studium (in particular, law schools) between the eleventh and the thirteenth century, 0 otherwise. A good reference is Rashdall (1987).

Family types: We adapt the classification proposed by Todd (1990) to the Italian specific regional differentiation following Del Panta et al. (1996). We code provinces according to the prevailing family type in the Middle Age and distinguish four types of families: incomplete stem, communitarian, egalitarian nuclear with delayed marriage, and egalitarian nuclear family with early marriage. 
Political regimes: This set of binary dummy variables is intended to grasp the long-run effect of different local systems of government in fourteenth century's Italy. We rely on the classification given by De Blasio and Nuzzo (2010) who distinguish Italian provinces in 5 groups: the Communal Republics, characterized by republicanism; the Signorie, under seignorial rule (Prince); the Papal State, characterized by a mixture of feudalism, tyranny, and republicanism; the Kingdom of Sicily, characterized by absolutism; and a residual category for those peripheral provinces which, at the beginning of the fourteenth century, were politically closer to foreign nations than to Italian local states (e.g., Sardinia and Western Piedmont).

Height: Data about wealth of ancient Italian provinces are not available. For this reason we employ height as a proxy for wealth. In the economic history literature it is common to make use of anthropometric measures because they provide important indirect information on changes in the well-being of the population. Data on height refer to the mean height of military conscripts aged 20 at the provincial level and are taken from A'Hearn et al. (2011, Table S3). For an exhaustive presentation of the use of this kind of anthropometric data as a plausible proxy for well-being and living standards see A'Hearn et al. (2011, ch. 2). For a discussion about the methodological approach employed to estimate average height see A'Hearn et al. (2009).

Industrialization: Data on industrialization at the provincial level are taken from Ciccarelli and Fenoaltea (2012, Table 2). The variable is a provincial index of relative industrialization calculated on the basis of census data as the share of industrial value added, excluding construction, over the share of the male population over age 15. Ciccarelli and Fenoaltea (2012) explain that using this age/sex group provides the best proxy of local GDP, because adult males represented the most mobile and flexible segment of the labor force and also because male labor force participation rates are uniformly high and not clouded, as female rates are, by varying local conventions. Data for the first wave refer to 1871 .

Literacy rates: Data on literacy are calculated on the basis of the 1861 Census that reports the number of people able to read or read and write aged 5 or more. Data for Veneto and Mantua refer to 1867 . They are taken from MAIC (1868) and come from wedding registers as the ability to sign one's name in full on a marriage certificate. Data for Rome refer to 1871 and come from MAIC (1906).

Ruling dynasties: This set of binary dummy variables are intended to capture the ruling dynasties immediately prior to Unification: the Savoy-Carignano, who ruled in the North Western areas of Italy, i.e., Piedmont, Liguria, and the island of Sardinia; the Habsburgs, who held direct control over Lombardy-Venetia in the North East, as part of the Austrian Empire, as well as indirect control over the Granduchy of Tuscany (Habsburg- Lorena) and other minor Duchies nearby (the Duchy of Modena under Este of Austria, the Duchy of Parma and Piacenza, and the Duchy of Massa Carrara under Habsburg-Lorena); the Pope, reigning over Rome and the Center South; and the Bourbons, in charge of the South and the Duchy of Lucca. Even though the latter falls under the Habsburgs in 
1847, we consider it as dominated by the Bourbons throughout the 1816-1861 period. Information is from Pécout (1999).

Table A2. Summary statistics

\begin{tabular}{|c|c|c|c|c|c|}
\hline Variable & Obs & Mean & Std. Dev. & Min & Max \\
\hline Schooling rate & 207 & 52.66921 & 24.63512 & 9.745636 & 117.3 \\
\hline Lower schooling rate & 207 & 48.15225 & 22.82749 & 8.600049 & 113.7153 \\
\hline Upper schooling rate & 207 & 4.469968 & 3.430144 & 0 & 25.5019 \\
\hline Male schooling rate & 207 & 56.88289 & 24.77012 & 13.00213 & 119.8 \\
\hline Female schooling rate & 207 & 48.24242 & 25.93999 & 3.767413 & 114.7 \\
\hline Female to male ratio schooling rate & 207 & 0.83175 & 0.208213 & 0.058806 & 1.515913 \\
\hline Female to male ratio upper schooling rate & 207 & 0.531752 & 0.262629 & 0 & 1.287918 \\
\hline Female to male ratio lower schooling rate & 207 & 0.824465 & 0.211084 & 0.04235 & 1.410763 \\
\hline Masculinity & 207 & 0.964414 & 0.022995 & .891104 & 1.053347 \\
\hline Medieval commerce & 207 & 0.521739 & 0.500738 & 0 & 1 \\
\hline Latitude & 207 & 42.69159 & 2.609697 & 37.04 & 46.11 \\
\hline Longitude & 207 & 11.97072 & 2.458898 & 7.33 & 18.11 \\
\hline Mountaneousness & 207 & 25.87739 & 25.38855 & 0 & 100 \\
\hline Sea & 207 & 0.5797101 & 0.494802 & 0 & 1 \\
\hline River & 207 & 0.4057971 & 0.492236 & 0 & 1 \\
\hline Urban population density & 207 & 0.010395 & 0.011219 & 0 & 0.060459 \\
\hline University & 207 & 0.391304 & 0.489225 & 0 & 1 \\
\hline Egalitarian nuclear family with early marriage & 207 & 0.304348 & 0.461246 & 0 & 1 \\
\hline Egalitarian nuclear family with delayed marriage & 207 & 0.231884 & 0.423059 & 0 & 1 \\
\hline Incomplete stem family & 207 & 0.130435 & 0.337598 & 0 & 1 \\
\hline Communitarian family & 207 & 0.333333 & 0.472547 & 0 & 1 \\
\hline Communal Republics & 207 & 0.2608696 & 0.4401734 & 0 & 1 \\
\hline Signoria & 207 & 0.2463768 & 0.4319452 & 0 & 1 \\
\hline Papal States & 207 & 0.1014493 & 0.3026546 & 0 & 1 \\
\hline Kingdom of Sicily & 207 & 0.3333333 & 0.4725473 & 0 & 1 \\
\hline Peripheral areas & 207 & 0.057971 & 0.2342551 & 0 & 1 \\
\hline Height & 207 & 163.2855 & 2.067145 & 158.1 & 167.4 \\
\hline Industrialization & 207 & 0.918889 & 0.32904 & 0.43 & 2.23 \\
\hline Literacy 1861 & 207 & 23.45184 & 13.08672 & 8.429249 & 58.6748 \\
\hline Male literacy 1861 & 207 & 30.33475 & 14.35486 & 13.19357 & 67.13915 \\
\hline Female literacy 1861 & 207 & 16.58197 & 12.38707 & 3.027826 & 50.95628 \\
\hline Female to male ratio literacy 1861 & 207 & 0.493192 & 0.183965 & 0.184799 & 0.891584 \\
\hline Savoys & 207 & 0.115942 & 0.320932 & 0 & 1 \\
\hline Habsburgs & 207 & 0.391304 & 0.489225 & 0 & 1 \\
\hline Pope & 207 & 0.173913 & 0.379954 & 0 & 1 \\
\hline Bourbons & 207 & 0.318841 & 0.467157 & 0 & 1 \\
\hline
\end{tabular}

